\title{
CONCENTRATIONS OF FREE AND ESTERIFIED CHOLESTEROL IN THE TESTES OF MATURING RABBITS
}

\author{
R. H. RENSTON, T. J. IHRIG, J. P. RENSTON AND B. GONDOS \\ Department of Pathology and Reproductive Endocrinology Center, \\ University of California School of Medicine, San Francisco, California 94143, U.S.A.
}

(Received 13th August 1974)

Summary. Levels of cholesterol and cholesterol esters were established in the testes of maturing New Zealand white rabbits. Free cholesterol levels remained relatively constant throughout pre- and post-pubertal development. The total cholesterol, cholesterol esters and percentage esterified cholesterol values were highest during the prepubertal period and decreased steadily thereafter, reaching their lowest after 90 days of age. Correlations of these findings with hormonal and morphological changes during testicular development are discussed.

\section{INTRODUCTION}

Testicular maturation is accompanied by variations in the levels of gonadotrophic (Courot, 1967; Winter \& Faiman, 1972) and steroid hormones (Lipsett \& Tullner, 1965; Warren, Haltmeyer \& Eik-Nes, 1973). Courot (1971) reported a 10- to 15-fold increase in LH during the prepubertal period in the lamb. Bartke (1971a) and others (Herbst, 1967; Behrman \& Armstrong, 1969; Behrman, Armstrong \& Greep, 1970; Behrman, Moudgal \& Greep, 1971; Moyle, Jungas \& Greep, 1973a) have postulated a direct rôle for LH in regulating cholesterol and cholesterol ester metabolism in the gonads of various species. While it is well established that cholesterol is the major precursor molecule in steroid biosynthesis (Strickland, Nayfeh \& French, 1970), information concerning the source, storage and metabolism of this neutral lipid in maturing testes is lacking. Previous studies attempting to characterize levels of cholesterol and cholesterol esters at various stages of testicular maturation in rats and mice have been inconclusive (Davis, Bridges \& Coniglio, 1966; Oshima \& Carpenter, 1968; Ichihara, 1969; Simmons, 1969; Bartke, 1971b).

This report characterizes levels of total, free, and esterified cholesterol in the testes of pre- through to post-pubertal rabbits, and correlates these findings with the hormonal and morphological changes which occur during testicular development.

\section{MATERIALS AND METHODS}

\section{Biopsy}

Testicular tissue was obtained at approximately 30-day intervals from New 
Zealand white rabbits ranging in age from 30 to 165 days. Anaesthesia was induced by intravenous administration of sodium pentobarbital (Diabutal: Diamond Labs, Inc.). The testes were removed and placed in ice-cold 0.9 $\mathrm{M}-\mathrm{NaCl}$ and the tunicae albugineae were removed.

\section{Lipid extraction}

Extraction of lipids followed the method of Folch, Lees \& Sloane Stanley (1957). Samples ( $1 \mathrm{~g})$ were homogenized with a Ten-Broeck homogenizer in 20 vols of $2: 1(\mathrm{v} / \mathrm{v})$ chloroform:methanol. The homogenates were filtered and the residues were re-extracted twice. All extracts were combined and the lipid was evaporated to near dryness using a rotary evaporator. The lipid was redissolved in chloroform, dried with anhydrous sodium sulphate, filtered, and aliquots were quantitatively removed for the neutral lipid separation. All steps were performed under nitrogen at room temperature.

\section{Thin-layer chromatography}

Aliquots of the unknowns and of the standard cholesterol and cholesterol ester mixture were plated on thin-layer chromatography plates pre-coated with silica gel ' $G$ ' (Analtech, Inc.). The plates were developed in a solvent system consisting of $80: 20: 1$ (by vol.) petroleum ether:diethyl ether:acetic acid for $1 \mathrm{hr}$ and were stained with iodine. Cholesterol and cholesterol ester spots were scraped, along with standards, and were eluted from the silica gel using chloroform. Samples were taken for cholesterol/cholesterol ester quantification.

\section{Cholesterol assay}

The method used for cholesterol/cholesterol ester determination followed that of Rudel \& Morris (1973). Samples were evaporated to dryness under nitrogen and $4 \mathrm{ml} \mathrm{O-phthalaldehyde} \mathrm{reagent} \mathrm{(Sigma} \mathrm{Chemical} \mathrm{Co.:} 25 \mathrm{mg} / 50$ $\mathrm{ml}$ glacial acetic acid) were added. After $10 \mathrm{~min}, 2 \mathrm{ml}$ concentrated $\mathrm{H}_{2} \mathrm{SO}_{4}$ were added. After $30 \mathrm{~min}$, the unknowns and standards were read using a Klett colorimeter (Klett Manufacturing Co., N.Y.).

\section{RESULTS}

The results shown in Table 1 indicate that the levels of free cholesterol remained

Table 1. Comparison of the levels of testicular cholesterol with age in rabbits

\begin{tabular}{ccccc}
\hline $\begin{array}{c}\text { No. of } \\
\text { animals }\end{array}$ & Age (days) & Cholesterol & Cholesterol esters & Total cholesterol \\
\hline 4 & $30 \cdot 0 \pm 0.0$ & $1 \cdot 18 \pm 0 \cdot 18$ & $1.23 \pm 0 \cdot 18$ & $2 \cdot 02 \pm 0 \cdot 30$ \\
7 & $60 \cdot 0 \pm 0.0$ & $1 \cdot 20 \pm 0 \cdot 12$ & $0.53 \pm 0 \cdot 17$ & $1 \cdot 73 \pm 0 \cdot 19$ \\
6 & $97 \cdot 0 \pm 2 \cdot 2$ & $1 \cdot 28 \pm 0 \cdot 15$ & $0.08 \pm 0 \cdot 04$ & $1 \cdot 35 \pm 0 \cdot 17$ \\
5 & $128 \cdot 4 \pm 3 \cdot 4$ & $1 \cdot 23 \pm 0.09$ & $0.07 \pm 0.06$ & $1 \cdot 30 \pm 0 \cdot 08$ \\
4 & $165 \cdot 3 \pm 1 \cdot 8$ & $1 \cdot 31 \pm 0 \cdot 12$ & $0.09 \pm 0.08$ & $1 \cdot 40 \pm 0 \cdot 16$ \\
\hline
\end{tabular}

Cholesterol values are given as $\mathrm{mg} / \mathrm{g}$ wet $\mathrm{wt}$ of testis, and all values given are expressed as mean \pm S.E.M. 


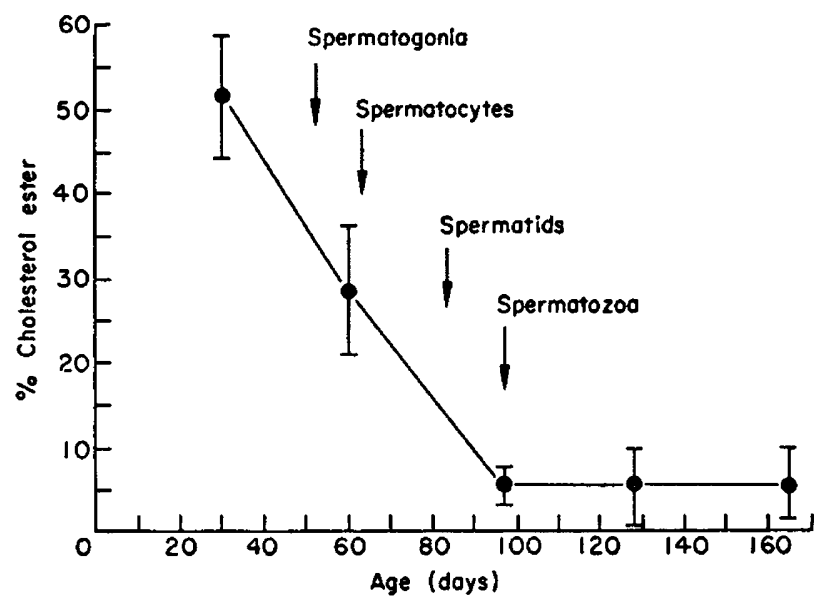

Texr-Frg. 1. The percentage of esterified cholesterol correlated with the age of the rabbit and with the stages of testicular germinal cell maturation (as indicated by Gondos, Renston \& Conner, 1973).

relatively constant in the testis from 30 to 165 days of age. Cholesterol esters, however, were at their highest level at 30 days of age and then decreased steadily throughout the prepubertal period to 90 days, subsequently remaining at their lowest level to the end of the observation period. The total cholesterol followed a curve similar to that of the cholesterol esters. The ratio of the cholesterol esters to the total cholesterol (Text-fig. 1) showed that approximately half of the total cholesterol at 30 days of age was esterified and that this ratio fell to a constant low value of $5 \%$ during the pubescent period from 30 to 90 days of age.

\section{DISCUSSION}

Characterization of levels of testicular cholesterol and cholesterol esters at different stages of maturation has yielded conflicting results. In mice, Ichihara (1969) reported a twofold increase in total cholesterol after weaning, while Simmons (1969) reported a rapid decrease in total cholesterol during the period preceding weaning. Others (Davis et al., 1966; Oshima \& Carpenter, 1968) have reported little or no change in these levels with maturation of rat testes. Bartke (1971b) reported slight decreases in total and esterifieds choleterol, and a slight increase in free cholesterol following the pubertal period in the mouse. $\mathrm{He}$ also reported a sharp decrease in the percentage of esterified cholesterol immediately preceding puberty.

Our data indicate that the level of free cholesterol in the rabbit testis remains relatively constant throughout pre- and post-pubertal development. The levels of cholesterol esters, however, are at their highest at 30 days of age and fall to their lowest value during pubescence. This is in agreement with the findings of Bartke (1971b). The percentage of esterified cholesterol follows the cholesterol ester curve rather closely. The total cholesterol level falls significantly during the prepubertal period and remains relatively constant thereafter. 
Because the fall in esterified cholesterol is accompanied by a decrease in total cholesterol, which is not reflected in a rise in free cholesterol, the esterified fraction of testicular cholesterol may be utilized for steroid biosynthesis. This is consistent with studies by Moyle et al. (1973b) on mouse Leydig cell tumours, by Behrman et al. $(1970,1971)$ on the rat and by Bartke (1971b) on the mouse, which indicate that cholesterol esters act as a precursor pool of cholesterol that is influenced by $\mathbf{L H}$, the levels of which are known to increase before and during puberty (Courot, 1971; Winter \& Faiman, 1972).

The fall in cholesterol esters coincides with the onset of the initial prepubertal spermatogenic cycle in the rabbit. Spermatogonia first appear in testicular tubules at 7 to 9 weeks and spermatozoa at 14 weeks (Gondos, Renston \& Conner, 1973). This is also the time during which the relative concentration of Sertoli cells declines. The correlation between cholesterol ester levels and Sertoli cell concentration is of interest in view of the suggested importance of Sertoli cells in early testicular development (Courot, 1971). Leydig cell maturation is also completed during this period (Gondos \& Conner, 1972) suggesting another possible relationship between morphological and biochemical events.

We have previously demonstrated that catalase activity falls sharply in the maturing rabbit testis (Ihrig, Renston, Renston \& Gondos, 1974) and, thus, follows a curve which is similar to that of cholesterol esters. Others (Svoboda, Azarnoff \& Reddy, 1969; Reddy, Svoboda \& Azarnoff, 1973) have observed both a proliferation of microbodies and elevated catalase activity following experimentally induced hypolipidaemia, suggesting that this microbodycontained enzyme is concerned in lipid metabolism. Caravaca, Dimond, Sommers \& Wenk (1967) administered catalase sub-units and found a decrease in serum and tissue cholesterol. Recently, Herzog \& Fahimi (1974) noted an association between microbodies and lipids in the mouse myocardium. Reddy $\&$ Svoboda (1972) have speculated that microbodies present in the testis may also have a function in lipid metabolism.

Further work correlating lipid levels with hormonal events would be valuable in determining the mechanisms regulating steroid synthesis in the developing testis.

\section{ACKNOWLEDGMENT}

This work was supported by grants HD-08202 and HD-08940 from the U.S. Public Health Service (B.G.).

\section{REFERENGES}

BARTKE, A. (1971a) Effects of prolactin and luteinizing hormone on the cholesterol stores in the mouse testis. F. Endocr. 49, 317-324.

Bartke, A. (1971b) Concentration of free and esterified cholesterol in the testes of immature and adult mice. F. Reprod. Fert. 25, 153-156.

Behrman, H. R. \& Armstrong, D. T. (1969) Cholesterol esterase stimulation by luteinizing hormone in luteinized rat ovaries. Endocrinology, 85, 474-480.

Behrman, H. R., Armstrong, D. T. \& Greep, R. O. (1970) Studies on the rapid cholesterol-depleting and steroidogenic actions of luteinizing hormone in the rat ovary: effects of amino-glutethimide phosphate. Can. F. Biochem. 48, 881-884. 
Behrman, H. R., Moudgal, N. R. \& Greep, R. O. (1971) Studies with antisera to luteinizing hormone in vivo and in vitro on luteal steroidogenesis and enzyme regulation of cholesterol ester turnover in rats. F. Endocr. 52, 419-426.

Garavaca, J., Dimond, E. G., Sommers, S. C. \& Wenk, R. (1967) Prevention of induced atherosclerosis by peroxidase. Science, $\mathcal{N} . r .155,1284-1287$.

Courot, M. (1967) Endocrine control of the supporting and germ cells of the impuberal testis. F. Reprod. Fert., Suppl. 2, 89-101.

Courot, M. (1971) Etablissement de la spermatogénèse chez l'agneau (Ovis aries). Doctoral thesis, University of Paris.

Davis, J. T., Bridges, R. B. \& Coniglio, J. G. (1966) Changes in lipid composition of the maturing rat testis. Biochem. F. 98, 342-346.

Folch, J., Lees, M. \& Sloane Stanley, G. H. (1957) A simple method for the isolation and purification of total lipids from animal tissues. F. biol. Chem. 226, 497-509.

Gondos, B. \& Gonner, L. A. (1972) Ultrastructural differentiation of interstitial cells in the fetal and postnatal rabbit testis. Biol. Reprod. 7, 118 , Abstr.

Gondos, B., Renston, R. H. \& ConneR, L. A. (1973) Ultrastructure of germ cells and Sertoli cells in the postnatal rabbit testis. Am. F. Anat. 136, $427-440$.

Herbst, A. L. (1967) Response of rat ovarian cholesterol to gonadotropins and anterior pituitary hormones. Endocrinology, 81, 54-60.

Herzog, V. \& FaHimi, H. (1974) Microbodies (peroxisomes) containing catalase in myocardium: morphological and biochemical evidence. Science, $\mathcal{N} . \Upsilon$. 185, 271-273.

IchiHARA, I. (1969) Cholesterol changes in developing testicular interstitial cells of the mouse: histochemical and biochemical study. Anat. Rec. 163, 595-598.

Ihrig, T. J., Renston, R. H., Renston, J. P. \& Gondos, B. (1974) Gatalase activity in the developing rabbit testis. 7. Reprod. Fert. 39, 105-108.

LipsetT, M. D. \& Tullner, W. W. (1965) Testosterone synthesis by the fetal rabbit gonad. Endocrinology, 77, 273-277.

Moyle, W. R., Jungas, R. L. \& GReep, R. O. (1973a) Influence of luteinizing hormone and adenosine $3^{\prime}: 5^{\prime}$-cyclic monophosphate on the metabolism of free and esterified cholesterol in mouse Leydig cell tumors. Biochem. F. 134, 407-413.

Moyle, W. R., Jungas, R. L. \& Greep, R. O. (1973b) Metabolism of free and esterified cholesterol by Leydig cell tumor mitochondria. Biochem. 7 . 134, 415-424.

Oshma, M. \& Garpenter, M. P. (1968) The lipid composition of the pre-pubertal and adult rat testis. Biochim. biophys. Acta, 152, 479-497.

REDDy, J. \& SvobodA, D. (1972) Microbodies (peroxisomes) in the interstitial cells of rodent testes. Lab. Invest. 26, 657-665.

Reddy, J., Svoboda, D. \& Azarnoff, D. (1973) Microbody proliferation in liver induced by nafenopin, a new hypolipidemic drug: comparison with CPIB. Biochem. biophys. Res. Commun. 52, 537-543.

Rudel, L. L. \& Morris, M. D. (1973) Determination of cholesterol using o-phthalaldehyde. F. Lipid Res. 14, 364-366.

Simmons, J. E. (1969) Changes in testicular cholesterol associated with estrogen induced infertility in male mice. F. exp. Zool. 170, 377-380.

Strickland, A. L., Nayfeh, S. N. \& French, F. S. (1970) Conversion of cholesterol to testosterone and androstanedione in testicular homogenates of immature and mature rats. Steroids, 15, 373-387.

Svoboda, D., Azarnoff, D. \& Reddy, J. (1969) Microbodies in experimentally altered cells. II. The relationship of microbody proliferation to endocrine glands. F. Cell Biol. 40, 734-746.

Warren, D. W., Haltmeyer, G. G. \& Erk-Nes, K. B. (1973) Testosterone in the fetal rat testis. Biol. Reprod. 8, 560-565.

Winter, J. S. D. \& Faiman, C. (1972) Pituitary-gonadal relations in male children and adolescents. Pediat. Res. 6, 126-135. 